\title{
Domestic Violence in U.S. Military Families
}

By

\section{Faten Bakr Nayitah}

\section{Major: Community Counseling}

Faten.nayitah@gmail. Com

\section{Abstract:}

This research paper discusses domestic violence in military families in the US. Currently, domestic violence is a widespread social problem, yet it is more of a problem in the military, a problem that is made worse by soldiers' numerous deployments to war zones. This research identifies the reasons, consequences, frequency of domestic violence in the military, and suggests effective solutions which could be implemented.

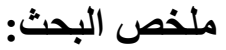

تنـاقش هذه الورقـة البحثيـة العنف الأسـري في العـائلات العسكرية في الولايـات المتحدة. ويعتبر العنف الأسري حاليًا مشكلة اجتماعية واسعة الانتشار، وتتز ايد هذه المشكلة بوضوح بين أسر اأفر اد الجيش و العسكريين، وهي مشكلة تزداد سوءًا بسبب الاثار النفسية على الجنود من عمليات الانتشار العديدة في مناطق الحرب. يحدد هذا البحث أسباب ونتائج و أنار العنف الأسري على عو ائل العسكريين والجيش، ويقتر ح حلو لا فعالة يمكن تتفيذها لاعم الأسر ومساعده أفر اد الجيش للعودة لحياتهم الطبيعية مع عو ائلهم بعد أنثار وتداعيات

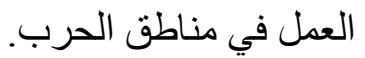




\section{Introduction:}

"Domestic violence has been identified as the number one cause of injury to women in the United States, exceeding car accidents, muggings and household accidents combined" (Tucker, 2009). Domestic violence is a common problem faced by the U.S. military families with soldiers who have returned from war. The problem of domestic violence in the military has many causes and serious effects on all family members. Controlling this problem, especially after increasing the number of soldiers in recent years, is the responsibility of many parties to find effective solutions to ensure the security of soldiers' families. Domestic violence in the military is a real and pervasive problem which has many negative effects on families like sexual assault and murder; as a result, the U.S. Department of Defense is developing many solutions such as provisional shelters for victims, raising awareness among soldiers, and activating treatment centers for offenders.

\section{Background:}

There are several interpretations of domestic violence. A definition is preferred by Jones (2012) is the U.S. Department of Defense's definition, because it considers domestic violence as a crime under U.S. law, and it is the most comprehensive definition which includes all parties to intimate relationships whether they are former or current. Types of domestic violence include several forms of abusive behaviors such as: emotional assault, psychological abuse, 
neglect, exploitation of finances, destruction of property, injury of pets, physical attack, sexual abuse, or murder. "Domestic violence in the U.S. Army is a growing concern. Research shows that the rates of domestic violence in the U.S. Military are two to five times higher than among the civilian population" (Stamm, 2009). It is important to know that women are often victims of domestic violence. The fact is that the victims of domestic violence in the military may be either women or men, but the studies show that the most likely victim of violence are women (Jones, 2012). Therefore, this research covers domestic violence against women in general.

\section{Discussion:}

\section{Causes Resulting from Military Labor}

Professional training in violence as a soldier is one cause of domestic violence with soldiers' families. The military life in the camps of the war is very different from the normal life with friends and family. It is based on using weapons to achieve the goals of the war, so for soldiers, the law of mercy is not acceptable there. Through the process of basic training, the military, habituates, normalizes, and values the use of violence as a necessity to achieve military objectives, and that's what makes the military a unique subculture in the U.S. (Bradley, 2007). Furthermore, this violence becomes part of the soldiers' personality. "I see it as a perpetual problem," said Dr. Catherine Lutz, an anthropologist and professor at Brown University's Watson Institute for International Studies who 
spent time in North Carolina researching domestic homicides at Fort Bragg, "basically, I think [the solution] has to involve demilitarization and the glorification of violence and that is what the military is: a giant machine for reproducing the idea that violence works" (as cited in Komp, 2006). The Military educates soldiers about how to use violence and fight and then soldiers practice it in the field of war for months or years. This negatively affects the lives of soldiers who only have the language of violence to deal with others. They tend to use violent language when dealing with marital problems. A culture of violence without restrictions is rooted in the veterans and soldiers personalities which drives them to deal violently with marital problems.

The cultural spillover theory explains why military husbands tend to be violent. Cultural spillover theory is the permission to use violence in the army which sometimes drives soldiers to use it in other, unacceptable areas of life such as being aggressive with their families. This theory shows the relationship between allowing and urging the use of violence by soldiers in army and the leniency of soldiers to deal with violently with their family members. Allowing violence in the army means more induction of violence into other fields of life even if aggression is not socially accepted (Bradley, 2007). One of these social areas that does not allow the use of violence is in the family at home; however, soldiers might be violent because violence becomes a culture of dealing with others. 


\section{Causes after war:}

There is a growing understanding of the relationship between mental health and intimate partner violence because of PostTraumatic Stress Disorder (PTSD) among soldiers. The survivors who have PTSD feel distant and numb with others, and they are irritable or depend on family or friends. This feeling may lead them to be less interested in social or sexual activities. The symptoms of PTSD drive survivors to have problems of trust, closeness, and communication with close family and friends, and these problems can create harmful relationships for their families or friends (Gerlock, 2004). The National Center for PTSD (2007) explains that as a consequence of survivors' behavior; their family and friends might also feel the survivors' feeling of anger or tension as a reaction to feeling that survivors cannot get over the trauma. This psychological disorder of PTSD by the soldiers increases the tension in the house which increases the probability of dealing violently with family members. Post-traumatic stress disorder is one of the most important causes of mental turmoil that pushes soldiers to use violence with their wives or their children.

\section{Causes at home:}

After the soldiers return from war, they want to restore their status inside their homes from their wives who took over additional responsibilities during their husbands' time of duty, so that leads to marital problems which contribute to the use of violence in the home. 
This is the time when the man becomes the decision maker at home and reclaims the authority which was previously possessed by the wife during his absence. During war time, when the husband is absent from home, the wife has complete responsibility of the house; however, upon the return of the soldier this absolute power is returned to him which leads marriages to have power struggle (Stam, 2009). This power struggle may be seen in different ways in intimate relationships. The article "Women Abused in Intimate Relationships" (2008) indicated that when the spouse wants to control his spouse, he could use many abusive patterns to force her to change her behavior to satisfy his demands. As a result of the struggle for power between couples, husbands after army service sometimes use domestic violence to try to seize power again.

\section{Effects on children:}

Children are the most affected victims of domestic violence. The effects of domestic violence on children might be emotional, social, behavioral or educational. There is a lot of literature which shows how children who have been exposed to domestic violence are more likely than their peers to experience a broad range of difficulties such as aggressive and antisocial behavior, depression, or other concerns. Child Welfare Information Gateway (2009) has concluded that children who are suffering of domestic violence face educational difficulties such as verbal and cognitive skills more than their peers who live without domestic violence in their home; 
furthermore, families who experience domestic violence often have high levels of cumulative risks which are ten times more likely to put kids in custody of the state than other children. All of these negative implications on children who live in a house which is dominated by domestic violence shows the extent of the damage that they are exposed to even if this violence is not directed directly to them.

Exposure of children to domestic violence increases the rate of domestic violence in the future. Disputes and methods of violence are watched by children from their parents become images in their memories which drive them to be violent people in their future. This effect is the long-term problem of domestic violence on children. "Research indicates that males exposed to domestic violence as children are more likely to engage in domestic violence as adults; similarly, females are more likely to be victims" (Child Welfare Information Gateway, 2009, p. 3). Domestic violence affects children mentally and psychologically. Furthermore, children who were victims of domestic violence are more likely to be adults who treat their families violently in the future.

\section{Murder:}

Murder and suicide are two other potential consequence of domestic violence in military families. According to studies, in 2010, in the U.S, there were 16 cases of murder under domestic violence, but 81 percent of them were by a soldier who returned from the military services. Domestic violence in the military is a multiplier 
quantity and quality than any other type of domestic violence. For instance, "Fort Bragg, North Carolina, [is] the source of many of the troops sent to Afghanistan. It was there that four soldiers recently confused their wives for the enemy and killed them ... All four couples had children, several now orphaned, because two of the men shot themselves after killing their wives" (Lutz, 2002). The experience of combat fighting in war and using weapons increases the likelihood of homicides and suicides.

\section{Drug and alcohol abuse:}

Drugs and alcohol are ways for soldiers to escape from posttraumatic feelings after the painful memories of the bloody wars. The soldiers after the war try to forget their painful and bloody memories. The National Center for PTSD (2013) wrote that $60 \%$ to $80 \%$ of Vietnam War veterans who sought treatment for PTSD who abuse alcohol may be a response to traumatic memories. Unfortunately, alcoholism and drugs are not just the problem, but because they are depressants, they may lead to suicide too. The National Center for PTSD (2013) pointed out that veterans who are older than 65 with posttraumatic stress disorder who also have issues drinking or depression are more likely to try suicide. Domestic violence may be an effect of taking alcohol and drugs which soldiers resort to forget the trauma after war. 


\section{Obstacles to solutions:}

This section is about the factors that double the incidence of domestic violence in the military or factors that hinder the effectiveness of solutions.

\section{Fear by the victims:}

Wives are wearied to do any reaction which makes them face more violence. This fear of consequences prevent them from asking for help or to file a complaint. The feelings of shame, isolation, and fear of reprisals are some concerns that hinder civilian and military victims of domestic violence from reporting domestic violence experience (Stamm, 2009). However, the victims of family violence in military are more controlled by fear of income losing. Lutz \& Elliston (2002) writes:

The difficulties women have in leaving their abusers are wellknown. Military wives have additional disincentives. The unemployment rate for military wives is extremely highhovering around 20 percent for those living at Fort Bragg - and those who do find employment are often stuck in the minimum-wage... If they report abuse, they risk not only retribution from their husbands, as do women in the civilian world, but loss of their total family income, healthcare and other benefits, and even their housing and neighbors if their husband is discharged. One Army program does provide $\quad \$ 900$ a month plus healthcare for 
the few abused women whose husbands are removed from the force for domestic violence (p. 4).

These concerns, which influence the wives' decisions, make them more likely to endure the husbands' assaults rather than bear the consequences of retribution and exposing the spouses to discharge and/or unemployment. Unfortunately, in the case of the victims who fled from their violent husbands to escape violence, they do not have proper shelter. For instance, there is no shelter for domestic violence's victims at Fort Bragg, and the local shelter, which the only place for fugitive wives, is donated ten dollars a day (Lutz and Elliston, 2002). By trying to control their fear of violence with lacking of shelters, some victims don't seek effective solutions.

\section{The Army Ignores the Problem:}

The Army is ignoring the problem for two reasons which are the public relations and the financial motives. In other words, the army is trying to bury the problem of domestic violence to keep its institutional interests. The military ignores the addressing of domestic violence because it spent the huge financial cost for training up to 1.4 million soldiers, for each soldier it has spent up \$100,000 for training; as a result, if it addresses the domestic violence problem the costs will rocket even more (Lutz, 2002). The huge sums which are spent on soldiers increase the pressure on the army because the army does not want to pay other massive sums for treatment of domestic violence. Biasing the army for its own interests hampers the 
effectiveness of solutions for the growing violence in the soldiers' and veterans' families.

\section{Inconsistent Levels of Severity and Categories:}

There are no strict punishments to deter the offender. Punishments should match fairly with the types of crime. Regrettably the proportion between the crime and the punishment for domestic violence cases is not in the military justice system. For example, the military considers a strangulation as a mild case of violence, but it would be considered a very hazardous and violent case in the civilian community (Stamm, 2009). Commutation of sentences on soldiers and veterans, with the gravity of the crimes which they might perpetuate against their families, reduces the victims' trust of the court system and increases the victims' surrender to offenders.

Moreover, this is not the only problem which is in consist severity levels of the crimes, but there is another problem which is not giving importance to all categories of domestic violence. "The categories place a heavy focus on physical abuse and take a very limited view of emotional abuse" (Stamm, 2009). Ignoring emotional abuse as a crime increases domestic violence because soldiers don't have any fear of punishment as compared to physically violent crimes. Disproportionate sanctions with crimes of domestic violence in the military court gives the offender a sense that he has the ability to elude his crime's punishment.

\section{Solutions:}


The Department of Defense (DoD) has taken many steps to control domestic violence and sexual assault problems in the military. For example, DoD has set up the Defense Task Force on Domestic Violence (DTFDV) to address cases of domestic violence from a central database (Somerville, 2009). More work is needed, however, because the provided efforts are not enough against the growing problem. Stamm (2009) wrote that since 1990, U.S army has had many broad improvements with domestic violence, but for progression, the army always needs review actions to make sure that rules and regulations retain well with the shifting trends. Also, the Army needs to intervene in incidences of domestic violence in their ranks in the same way that other law enforcement agencies address the problem. The cure for the problem of domestic violence and the need two-steps. They are the treatment which means security of victims and prevention which means rising awareness among soldiers and their families.

\section{Security of victims:}

The insurance protection for victims begins when military police receive their calls and complaints. Lutz and Elliston (2002) state that "Women have spoken out about the frequent failure of commanders to take their calls for help seriously. And they have complained that they were often sent to military chaplains" (p. 4). Communication of this type would be a very important step to ensure their safety. This failure may be because the lack of community 
helplines in the military culture to receive these issues and complaints if they occur. Moore said that community needs to report abuse as soon as it happens for the military police to help victims of DV by the helplines which are available 24 a day hours (as cited in Gatchell, 2013). The fast response will help to protect the victims immediately, and it will be a source of security for the victims and a deterrent to offenders.

In addition, as pointed out the lack of targeted sanctions to fit the levels of domestic violence in the military court as federal court has, appropriate punishment with the crimes' levels is another deterrent for soldiers to attack their wives and children because of fear from strict punishment. To determine how appropriate sanctions of severity influence the crime rate, Reynolds, Senior Fellow Director of the NCPA Criminal Justice Center (1998) explains the low crime rate from 1991 to 1997 . He indicated that the crime rate decreased to approximately $30 \%$ within six years. The explanation for this is that the courts have become stricter in their sanctions and sentencing in order to make them more appropriate to the level of the crimes. Fear was used as a tool to deter criminals from getting these sanctions to reduce the proportion of crimes. In other words, if the military courts re-considered the sanctions to be proportional, it would be a part of the resolve this problem which could the reason that the domestic violence is low in civilians. The military should redouble efforts to address the problem of domestic violence, such as 
the appropriate punishment which is an important factor to decrease the rate of domestic violence in the future.

\section{Raised awareness about how to deal with returning soldiers:}

The right way of dealing with soldiers to contain them and help them to overcome PTSD is the awareness which is a fundamental solution to help them return to their lives with family again. There are many efforts that are made by U.S. Ministry of Defense to address the problem of domestic violence in military. The Department of Defense (DoD) and National Control of the Domestic Violence Awareness defined October as the month to reminding the military community about resources and programs to help in the prevention of domestic violence (Miles, 2010). Raising awareness of domestic violence among soldiers is protection for soldiers from the violent thought. All of these efforts to support an awareness program against domestic violence is an indication of the positive impact awareness has in declining this social problem.

Also, the awareness programs help soldiers to refresh the relations with their families and friends. Relations with others are very important for trauma survivors because the social support is one of the best ways to protect against getting PTSD. Rebuilding relationships can offset feelings of being alone and can be can be supportive when survivor deals with the pressures after trauma (The National Center for PTSD, 2007). Repairing bonds of emotion may also help the survivor's self-esteem. This may help reduce depression 
and guilt. A relationship can also give the survivor a way to help someone else. Helping others can reduce feelings of failure or being cut off from others. The awareness is as bridge to renew relationships between soldiers and their families and friends to supports soldiers to exceed the PTSD.

\section{Conclusion and Future Research:}

Domestic violence in the families of soldiers returning from war is a serious problem which affects society. It causes to several serious effects for short and long terms on all family's members including children. There are many offered solutions to address this problem. Nevertheless, there are many obstacles that prevent solutions' effectiveness. Future studies should focus on how the military has the insurance of protection and rehabilitation for each of the soldiers or their families and how to effective the efforts of U.S army to help them. If the military can reduce the domestic violence among soldiers' families, it would achieve one of the greatest medal of pride, happiness within the home. 


\section{References}

- Alberta Children and Youth Services Prevention of Family Violence and Bullying. (2008). Women Abused in Intimate Relationships. Retrieved from: http://www.familyviolence.alberta.ca

- Bradley, C. (2007). Veteran Status and Marital Aggression: Does Military Service Make a Difference? Journal of Family Violence, 22(4), 197-209. doi:10.1007/s10896007- 9072-4

- Child Welfare Information Gateway, (2009). Impact of Domestic Violence on Children. U.S. Department of Health and Human Services. doi:10.1016/j.avb.2011.12.002

- Gerlock, A. A. (2004). Domestic Violence and Post-Traumatic Stress Disorder Severity for Participants of a Domestic Violence Rehabilitation Program. Military Medicine, 169(6), 470-474.

- Jones, A. D. (2012). Intimate partner violence in military couples: A review of the literature. Aggression \& Violent Behavior, 17(2), 147-157.

- Komp, C. (2006). Domestic Abuse in Military Families Growing. The NewStandard. Retrieved from: http://newstandardnews.net/content/index.cfm/items/32 71

- Lutz, C., \& Elliston, J. (2002). DOMESTIC TERROR. Nation, 275(12), 18-20.

- Stamm, S. (2009). Intimate Partner Violence in the Military: Securing Our Country, Starting With the Home. Family Court Review, 47(2), 321-339. doi:10.1111/j.1744- $\quad$ 1617.2009.01257.x

- The National Center for PTSD, (2007). Relationships and PTSD. U.S. Department of Veterans Affairs. Retrieved from: http://www.ptsd.va.gov/public/pages/ptsd-andrelationships.asp

- The National Center for PTSD, (2013). PTSD and Problems with 
Alcohol Use. U.S. Department of Veterans Affairs. Retrieved from:

http://www.ptsd.va.gov/public/pages/ptsd-alcoholuse.asp

- Tucker, D. D. (2009). Domestic Violence, PTSD and Brain Injury: Military and Civilian Challenges - Part 1. Relieved from http://www.ncdsv.org/

- Somerville, K. J. (2009). The Military Report Card Concerning Domestic Violence and Sexual Assault, Including Compliance with the Lautenberg Amendment. Family Law Quarterly, 43(2), 301-314

- Gatchell, B. (2013). USAG Ansbach holds Purple and White Night to raise domestic violence awareness. U.S. Army.

Relieved from http://www.army.mil/article/114987/

- Reynolds, M. O. (1998). Does Punishment Deter? National Center for Policy Analysis. Relieved from http://www.ncpa.org/pub/bg148

- Miles, D. (2010). Military Launches Domestic Violence Awareness Campaign. The U.S. Department of Defense. Relieved from http://www.defense.gov/news/newsarticle.aspx?id=611 31

- Alberta Children and Youth Services Prevention of Family Violence and Bullying. (2008). Women Abused in Intimate Relationships. Relieved from www.familyviolence.alberta.ca. 